17

\title{
أ.د. نبيلة حساني
}

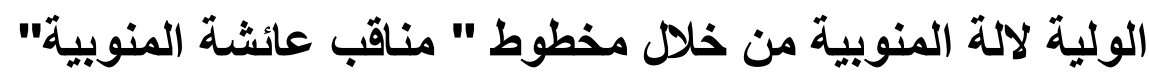

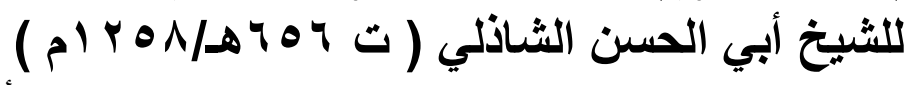

يزخر التاريخ الاسلامي بذكر أسماء العديد من المتصوفين الذين كان لهم تأثير الثير

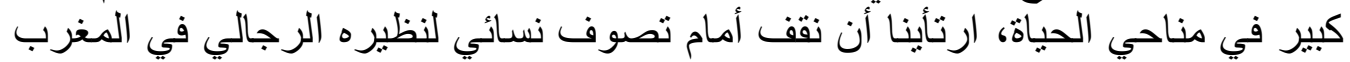

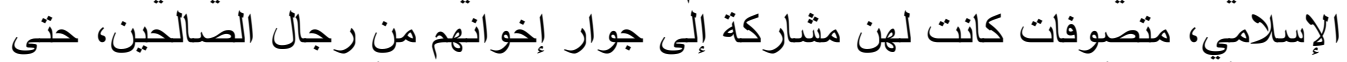

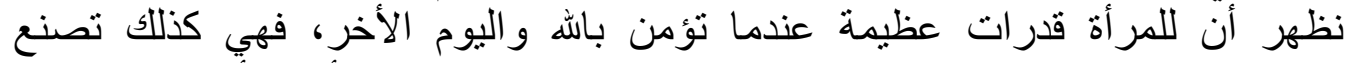

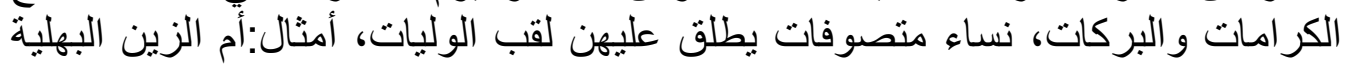

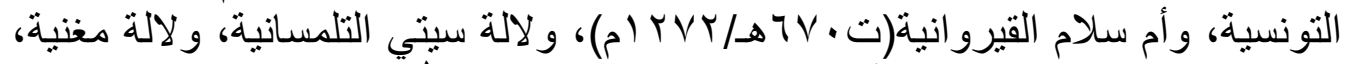

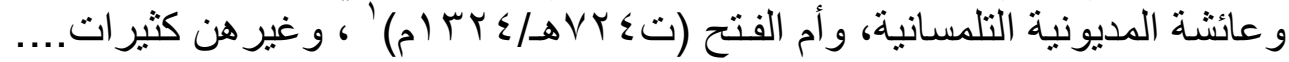

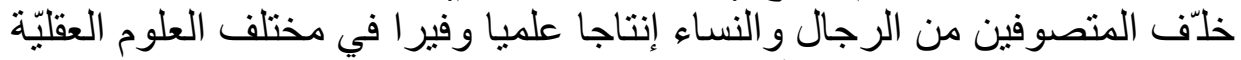

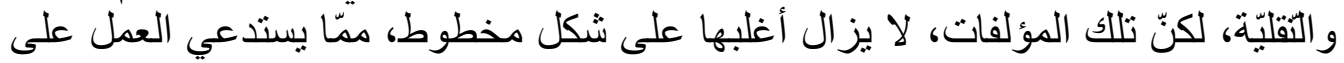
تحقيقها و نشر ها. ت كنا.

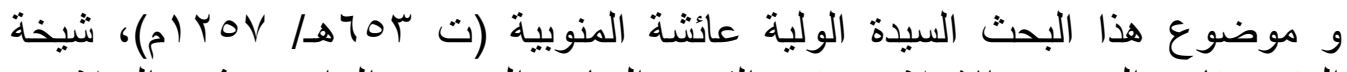

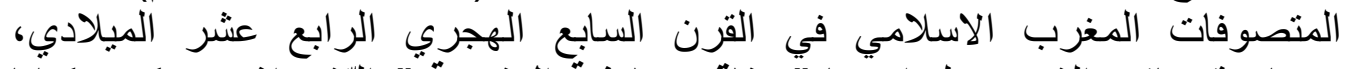

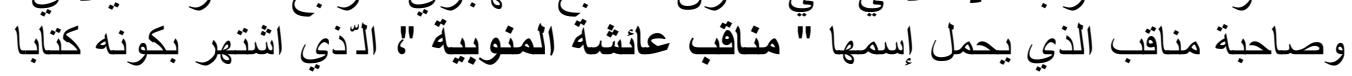

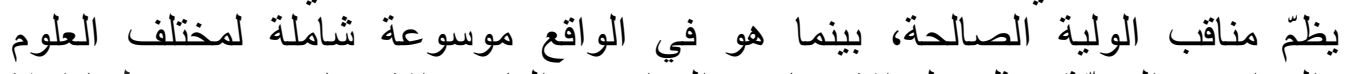

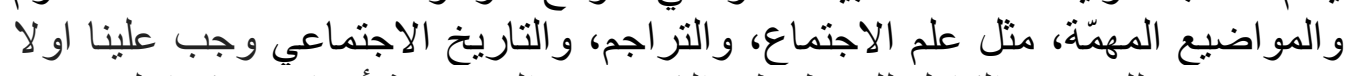

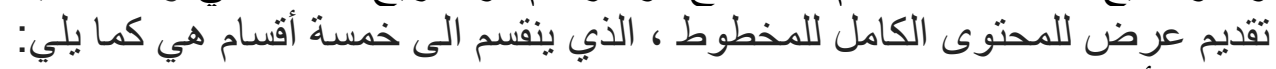
القسم الأول: في تعريف باسمها ونسبها.

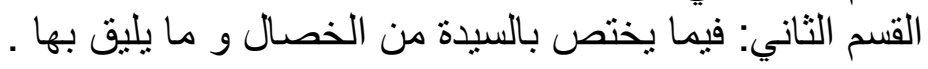

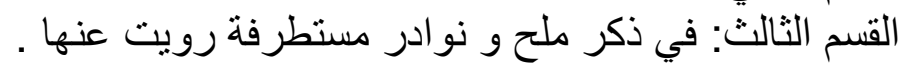

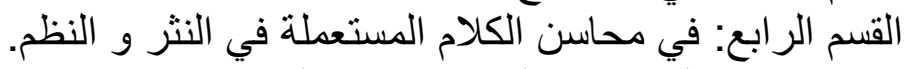

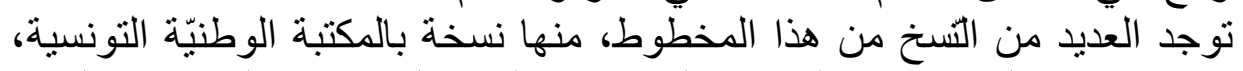

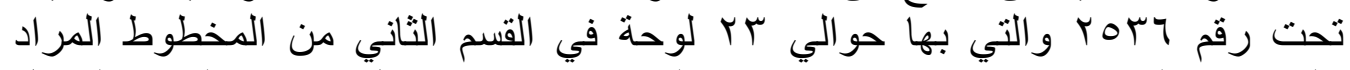

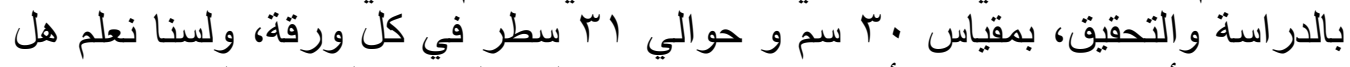

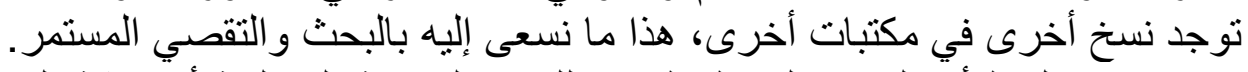

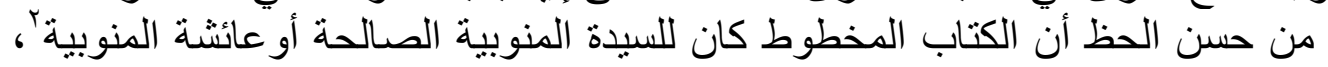
و أنها سيدة تونسية عرفت بالتو اضع و البركة و الحنانة و العفة، هي بنت الثيخ أبي الثي موسى الينى

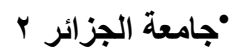

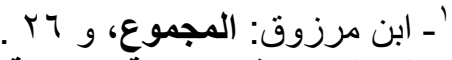
؟ـ الثناذلي: مناقب عائثة المنوبية، و 19. 


\section{7 دراسات في آثار الوطن العربي 17}

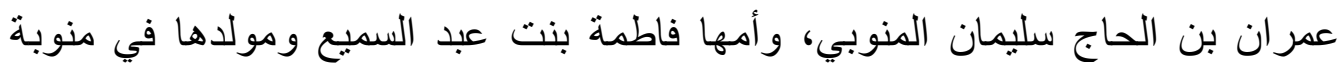

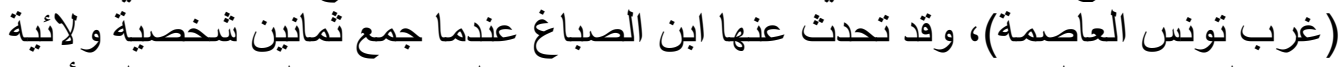

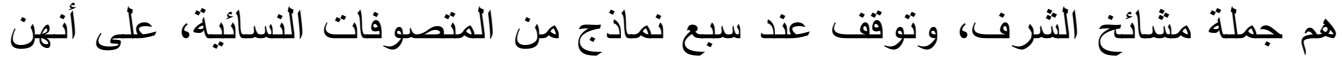

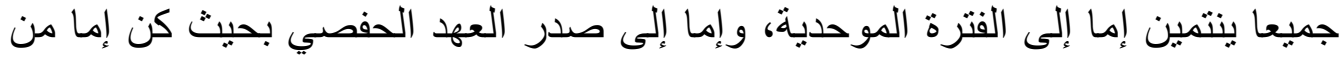

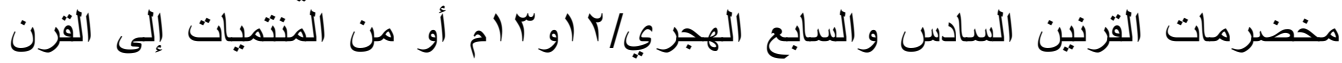

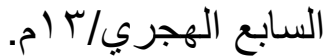
كانت عائشة الكنوبية صالحة، متعبدة، حسنة الخلق، لها جمال وحسن فائق و إذا نظر

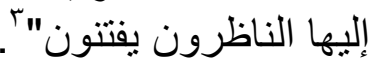

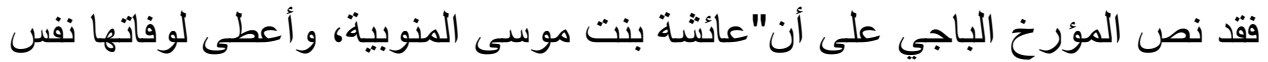

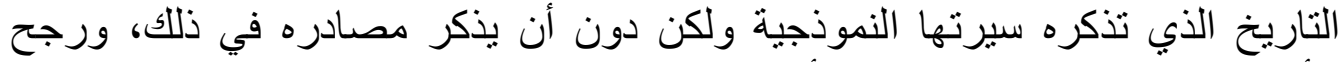

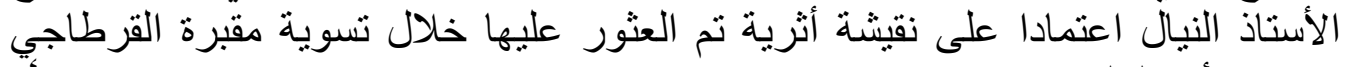

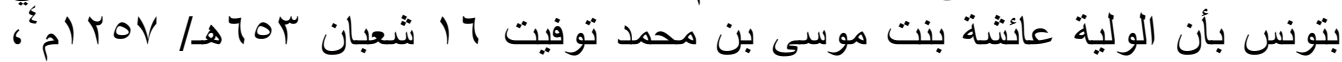

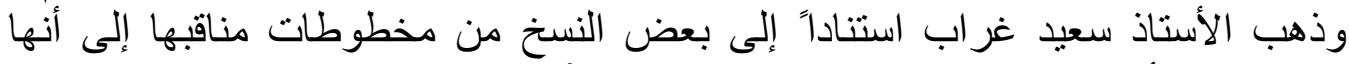

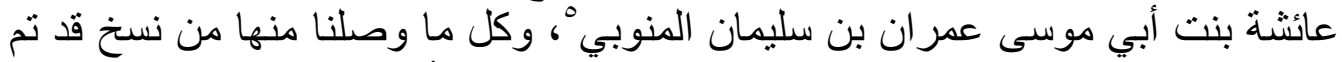

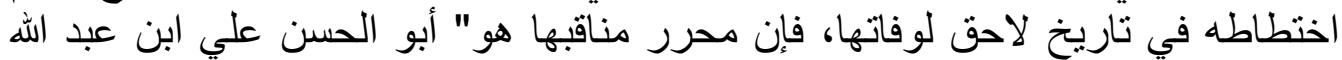

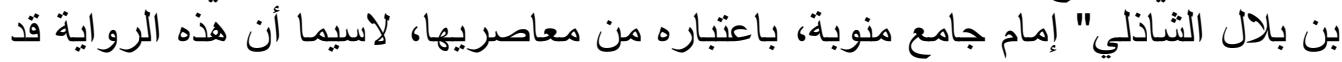

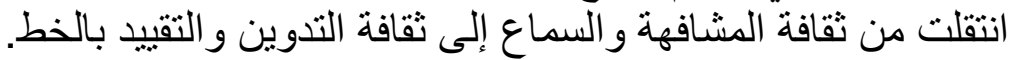

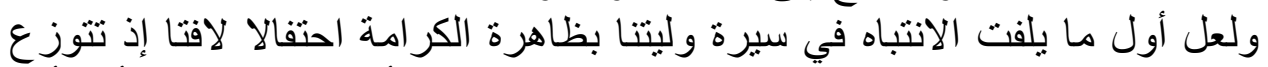

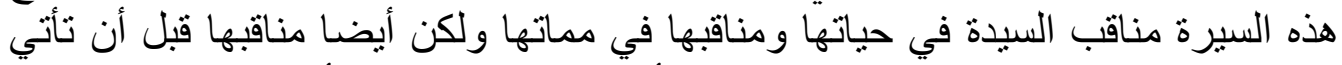

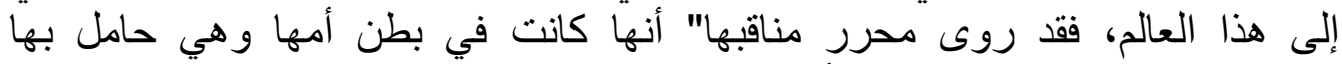

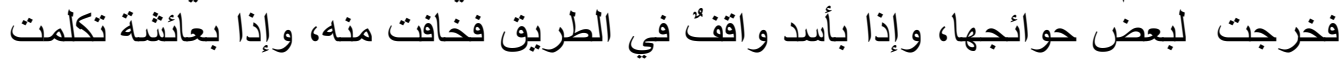

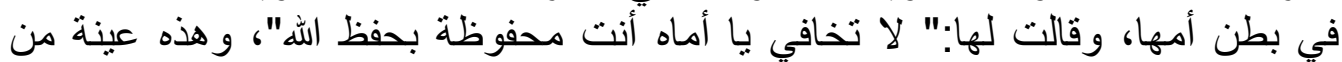

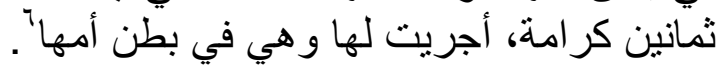

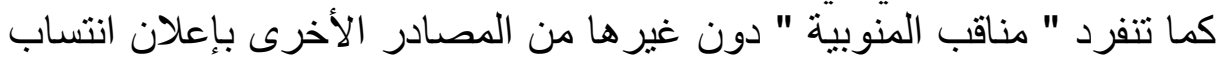

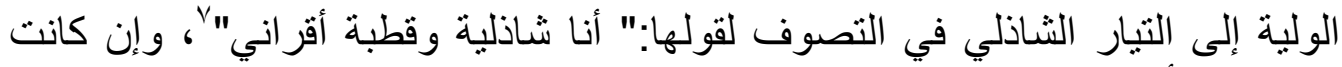

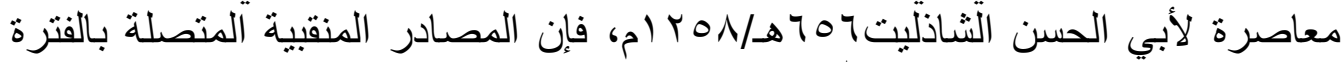

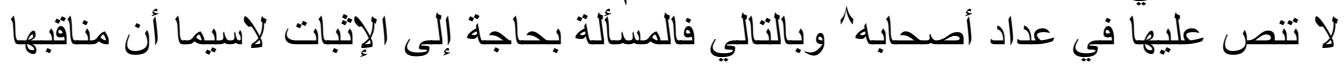

5. GHRAB (S) :IBN ARAFA et le Malikisme en Ifriqiya au 8h-14, Tunis,1992, P 68

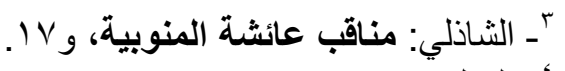

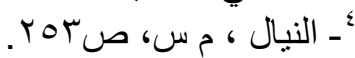

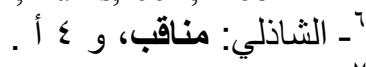

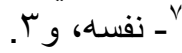

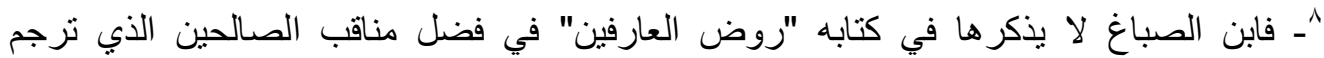

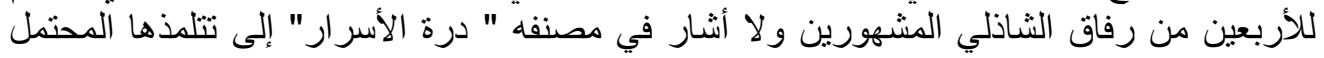




\section{دراسات في آثار الوطن العربي 17}

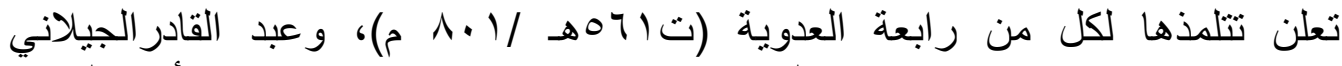

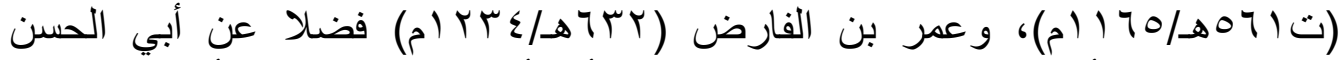

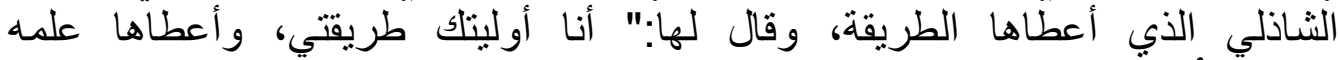

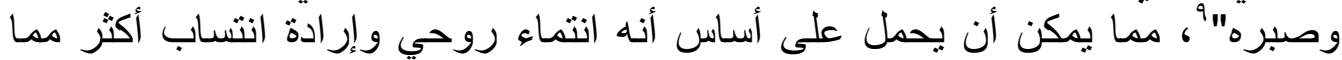

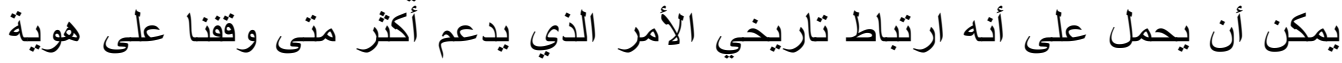

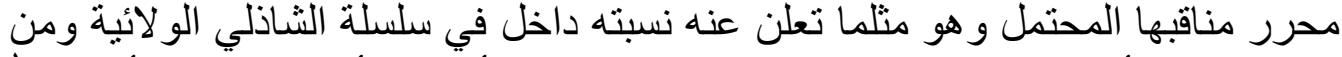

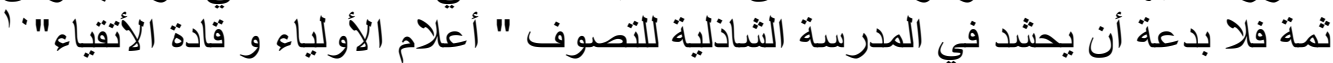

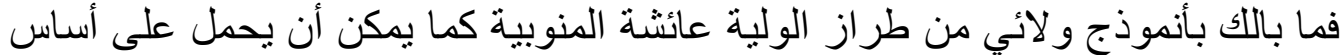

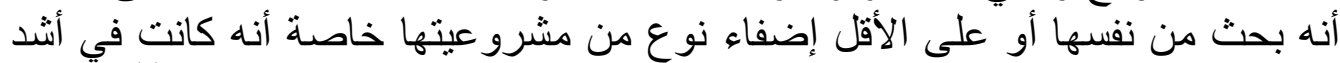

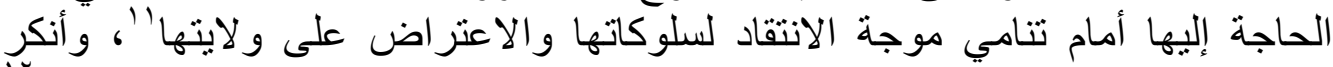

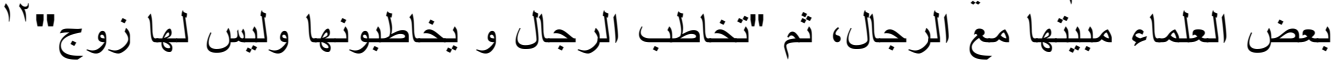

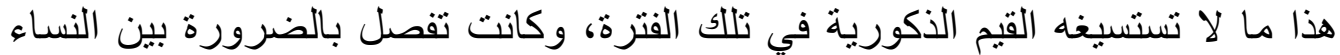

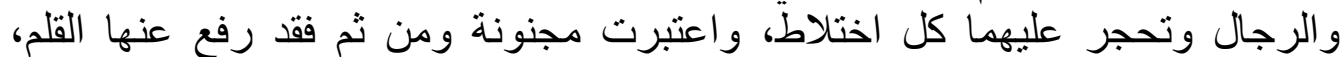

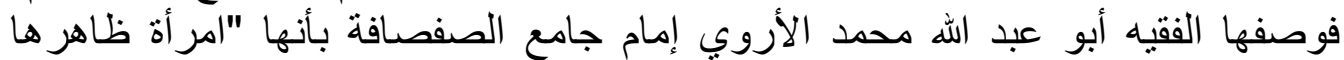

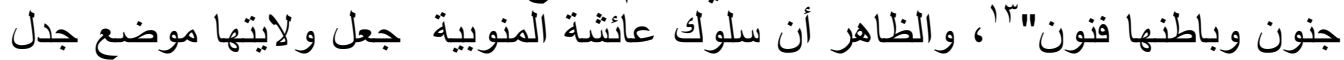

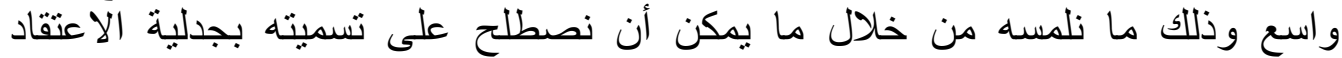

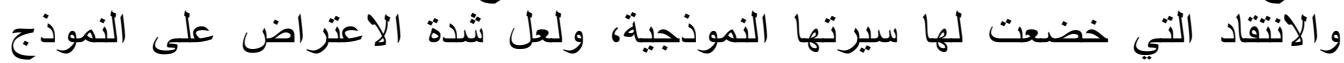

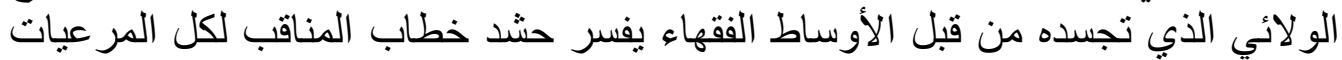

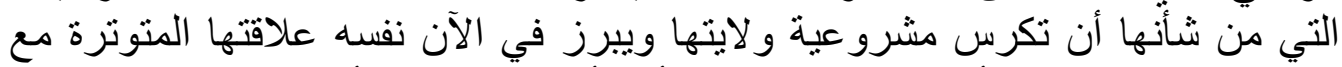

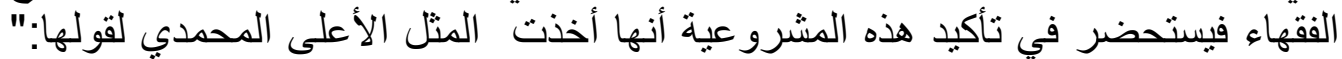

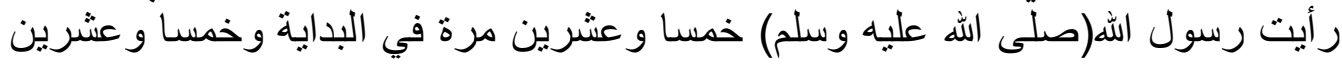

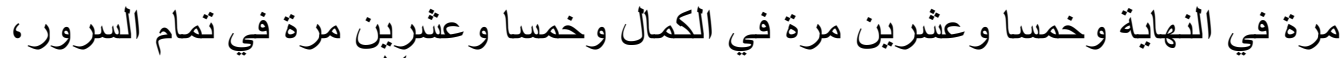

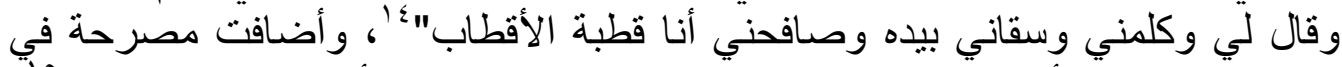

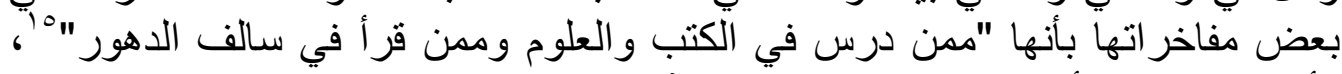

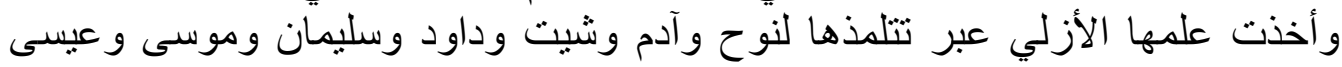

عليه أثناء المرحلة التونسية من مسيرة حياته مما يجعل هذا التتلمذ مدعاة للشك ويجعل انتماء السيدة

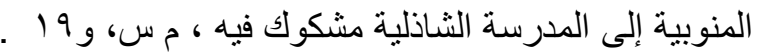

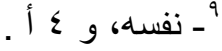

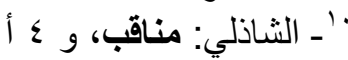

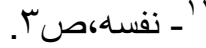

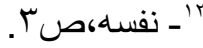

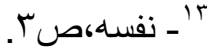

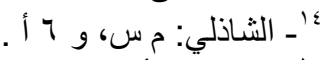

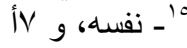


وشعيب، وأخذت المثل الأعلى الراشدي ممثلا في تتلمذها المفترض لأبي بكر الصديق

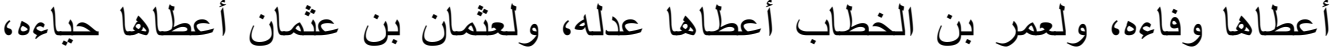

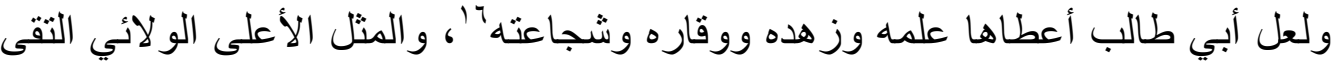

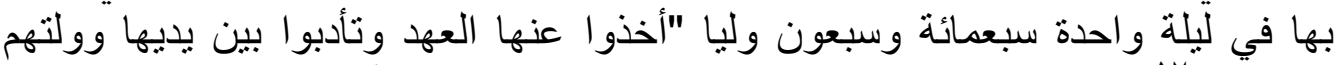

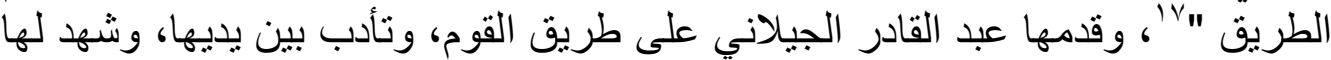

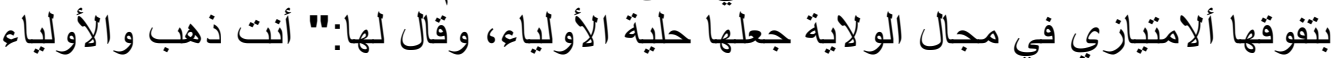

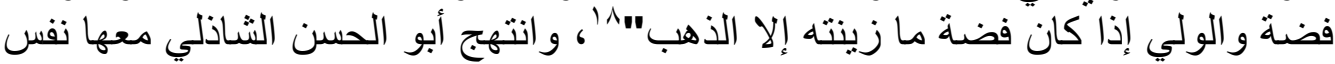

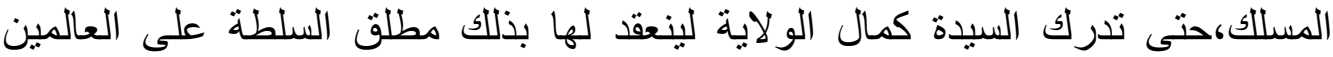

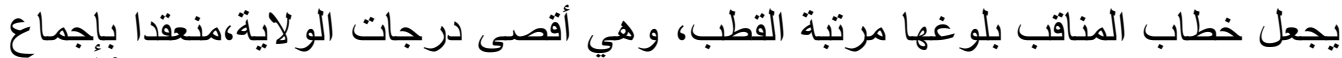

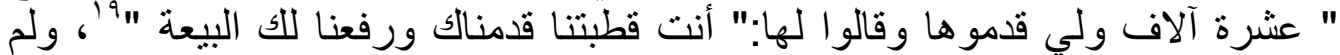

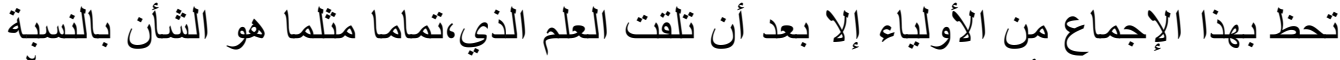

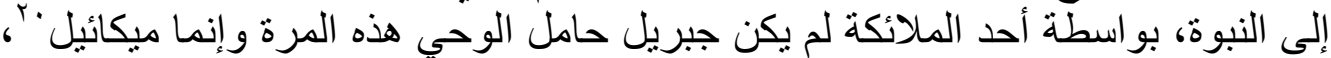

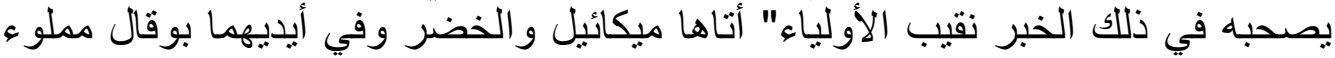

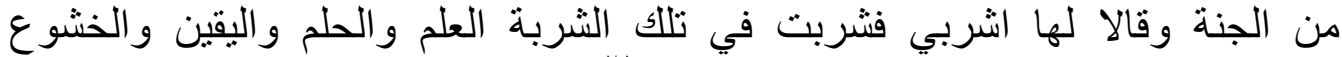

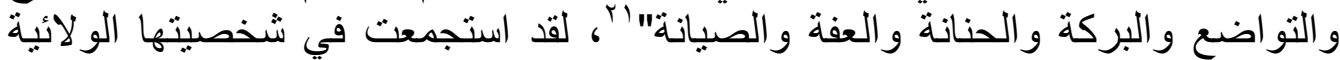

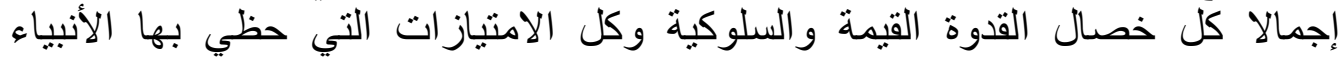

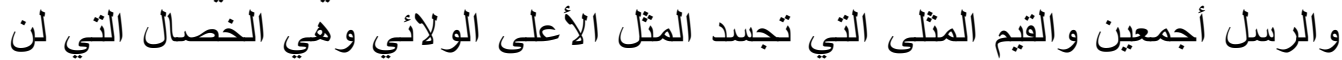
تكتفي فقط بإضفاء المشرو عية على و لايتها و إنما سترتقي بهذه الإني الو لاية إلى مرتبة الكية الكمال

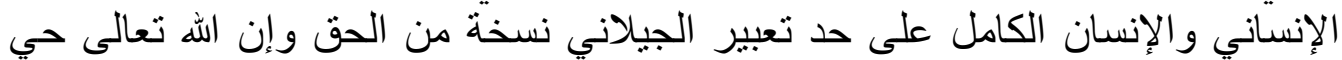

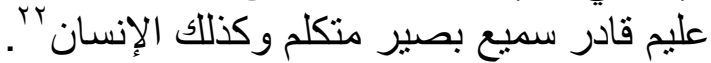

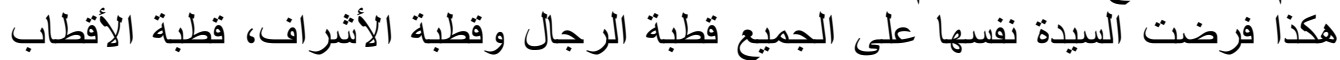

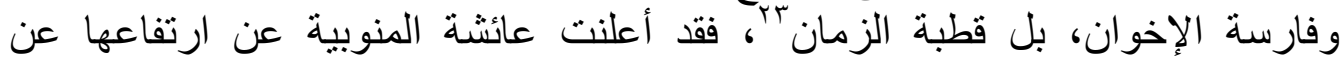

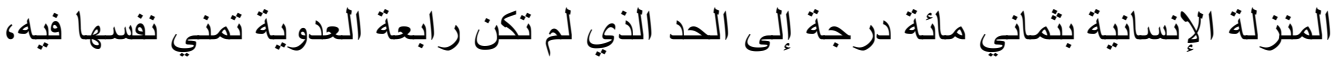

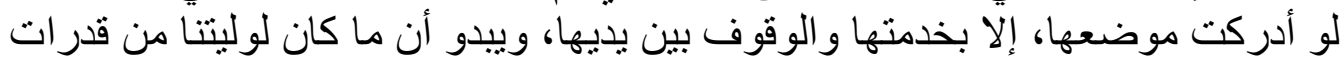

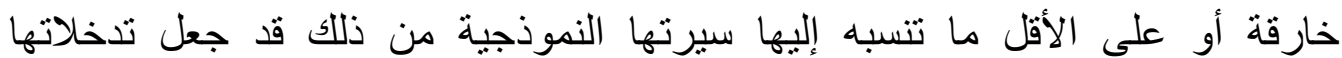

$$
\begin{aligned}
& \text { ـ ـ نفسها،. و } 1 \text {. } 19
\end{aligned}
$$

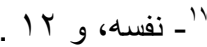

$$
\begin{aligned}
& \text { 1' ـ نفسه، و } 10 .
\end{aligned}
$$

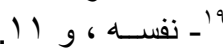

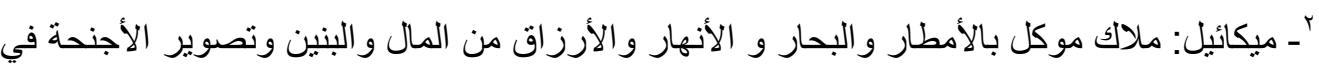

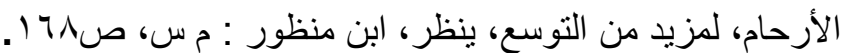




\section{دراسات في آثار الوطن العربي 17}

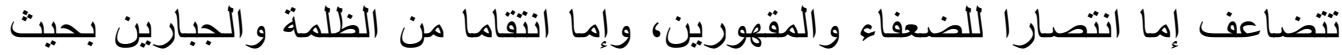

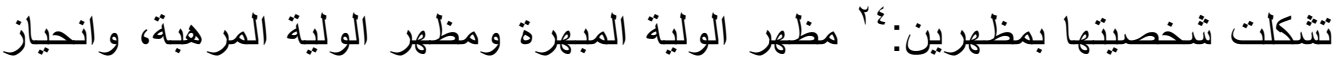

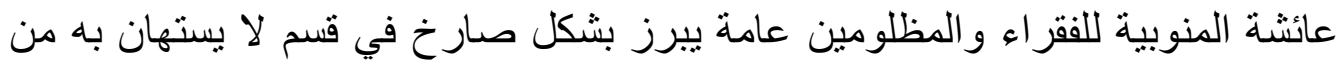

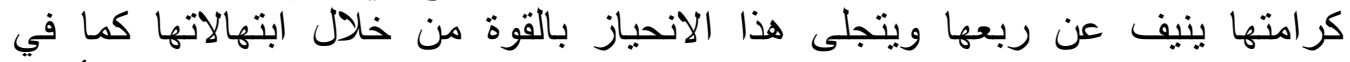

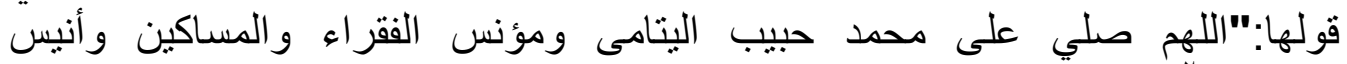

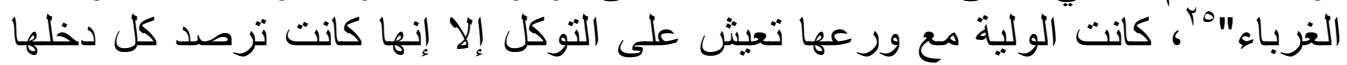

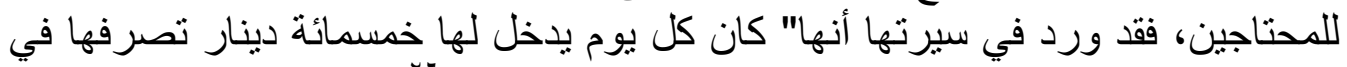

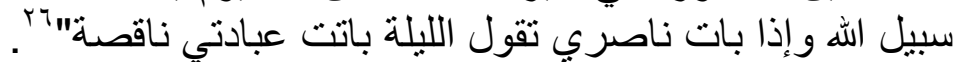

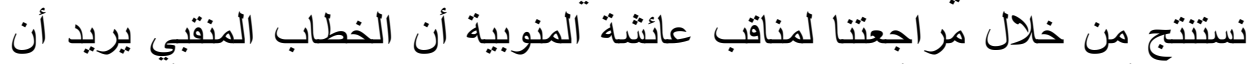

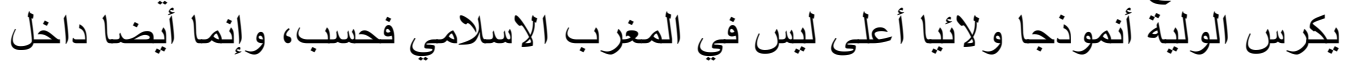

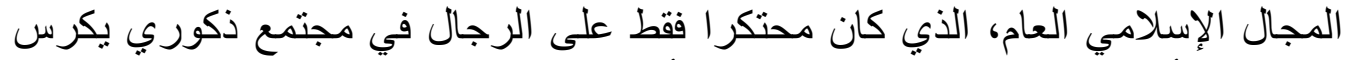

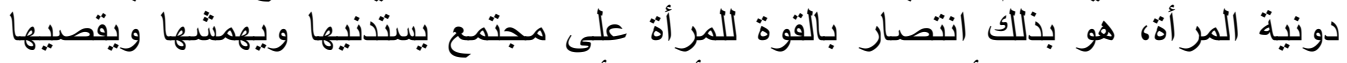

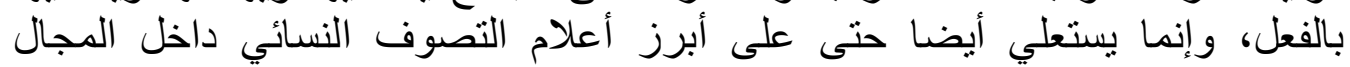

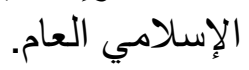

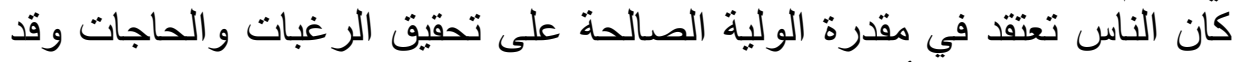

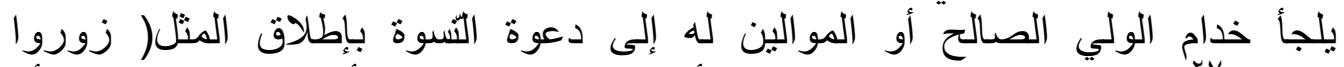

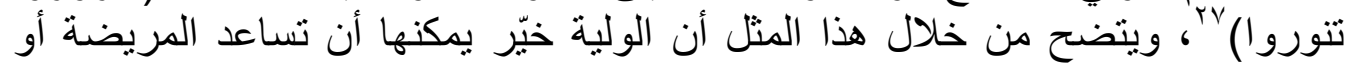

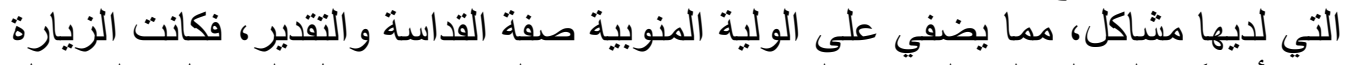

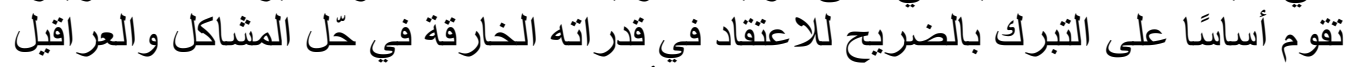

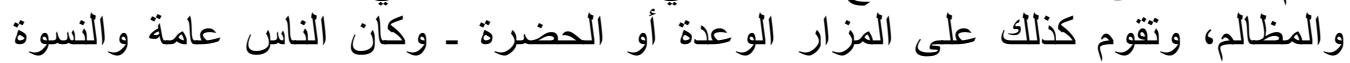

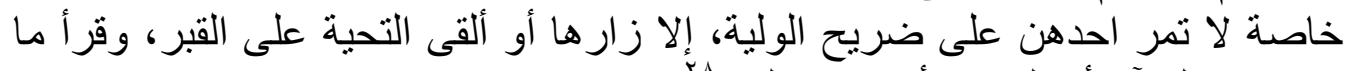

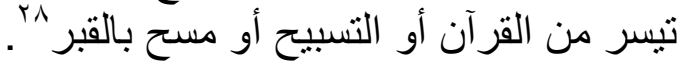

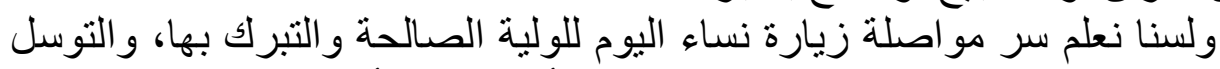

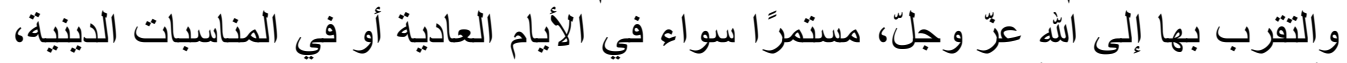

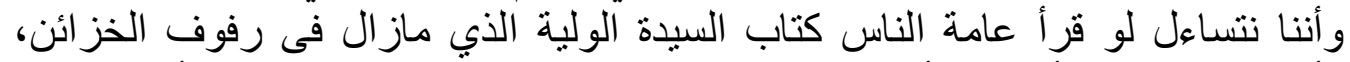

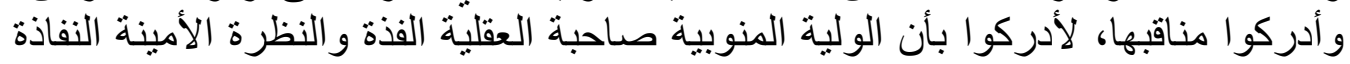

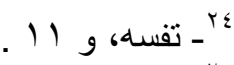

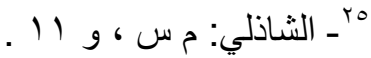

$$
\begin{aligned}
& \text { بr }
\end{aligned}
$$

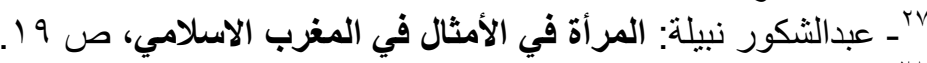

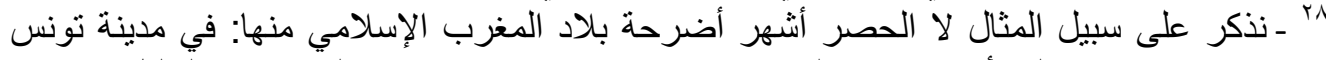

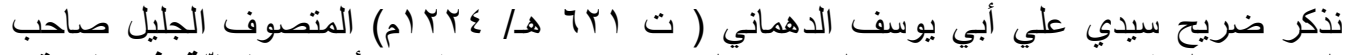

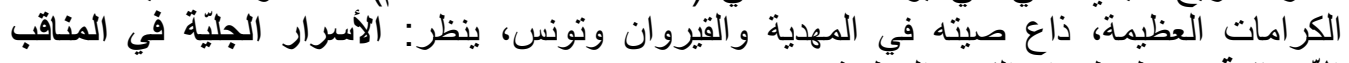
الآهمانية، مخطوط بدار الكتب الوطنية بتونس. 


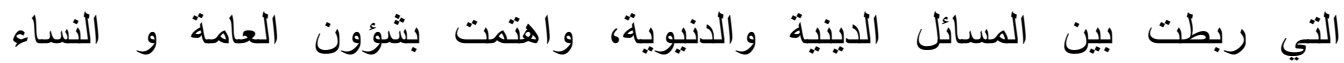

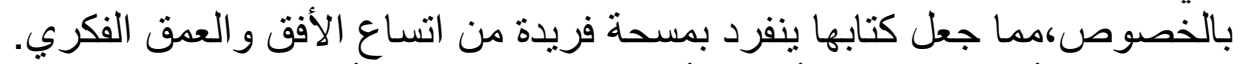

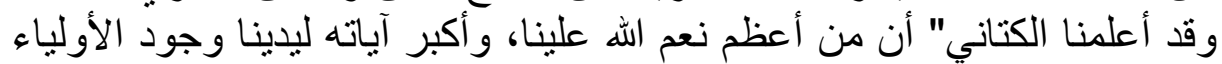

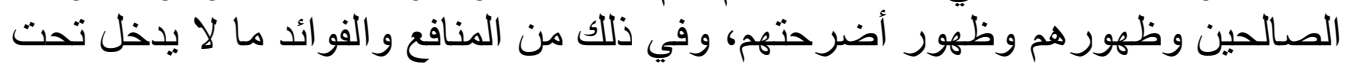

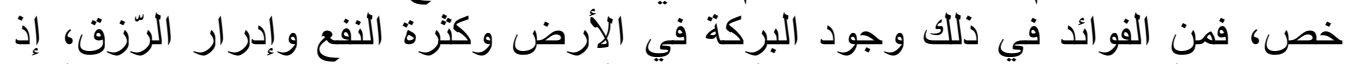

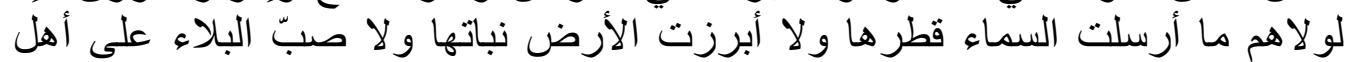

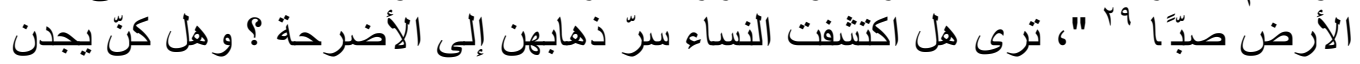

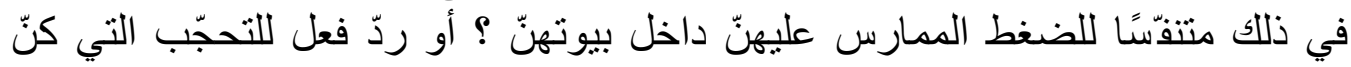

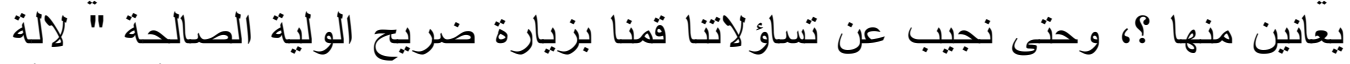

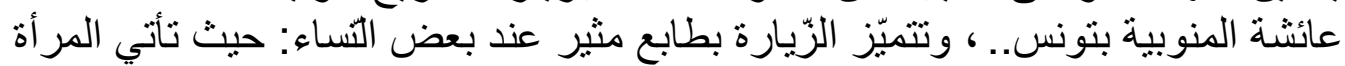

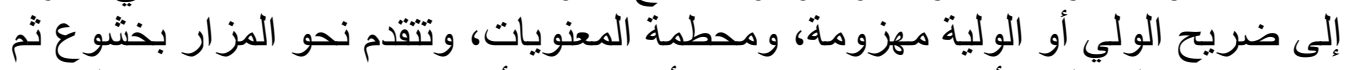

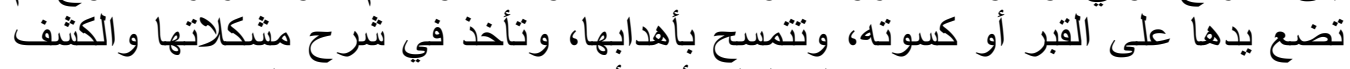

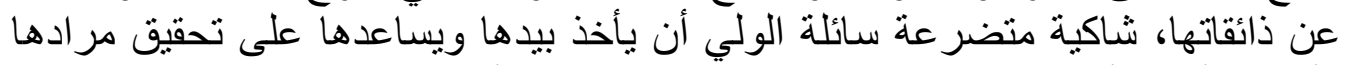

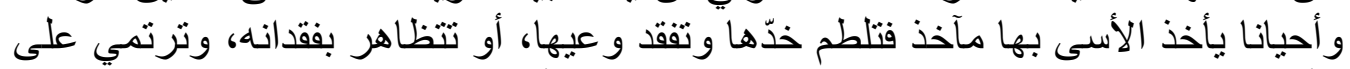

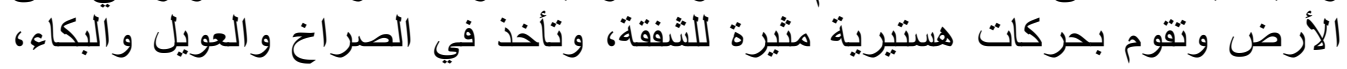

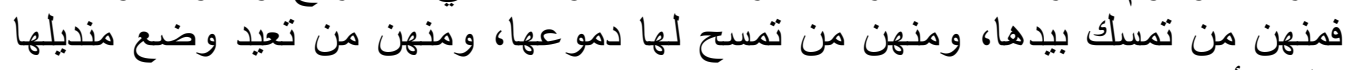

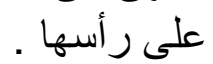

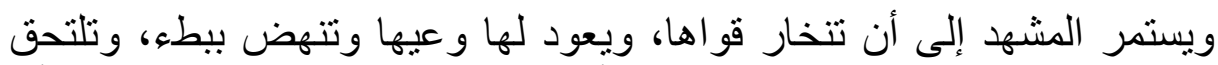

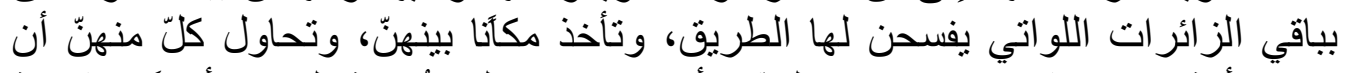

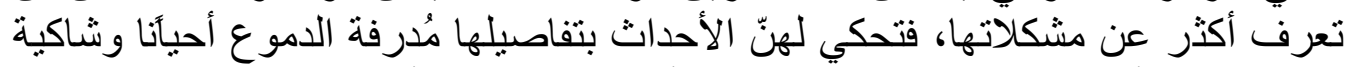

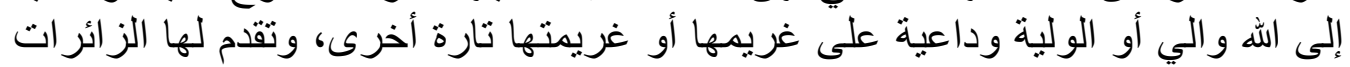

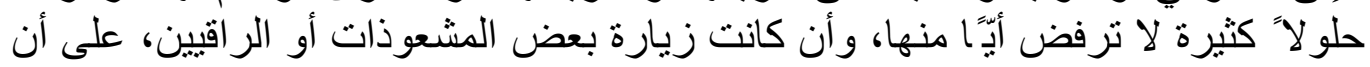

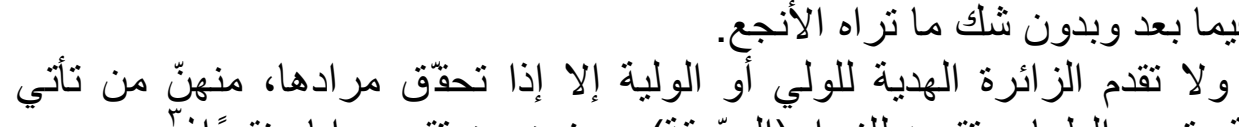

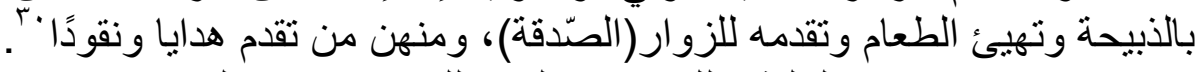

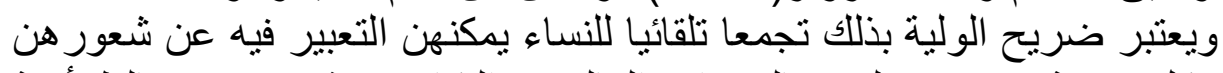

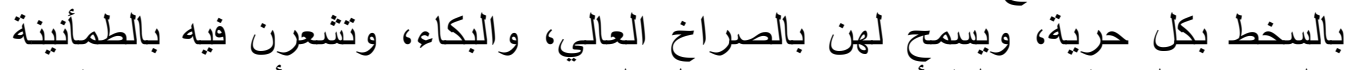

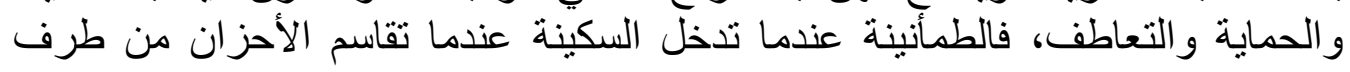
الز ائرات. - ماته

9 ' - الكتاني: سلوة الأنفاس ومحادثة الأكياس بمن أقبر من الطماء والصلحاء بفاس، ط، حجرية

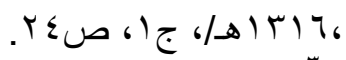

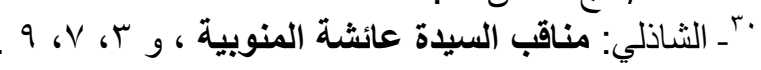




\section{لدراسات في آثار الوطن العربي 17}

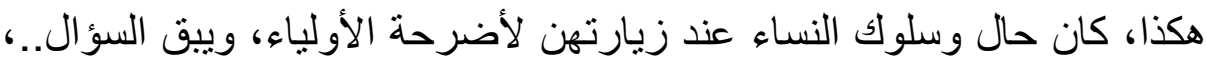

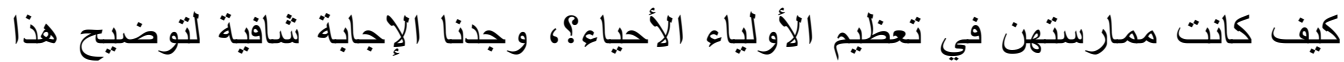

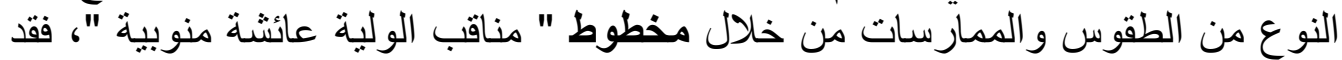

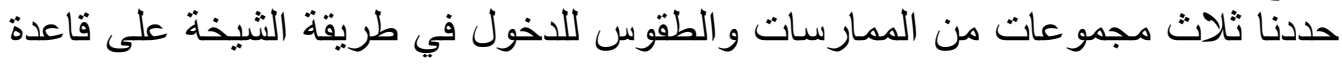

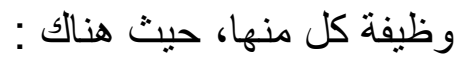
ـ مجموعة أولى، طقوس الدخول في طريقة الثيخة الولية منوبية و المتمثلة في (معاهدة،

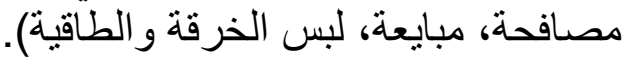
. مجموعة ثانية، ذات الوظيفة المسارية ( initiatique ) و المتمثلة في (تفل في الفم، سقاية ورضاعة): ـ ومجموعة ثالثة، ذات الوظيفة الثفائية و المتمثلة في (تفل، رقية ومسح). ويتم ذلك بـ : أ - بعض طقوس وممارسات الدخول في طريقة الثيخة منوبية:

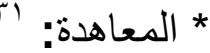
وفحو ها تتمثل في:

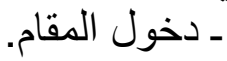

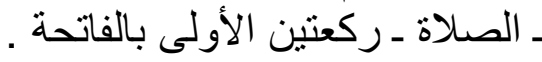
ـ ـ استقبال القبلة. ـ نطق بالتعهد.

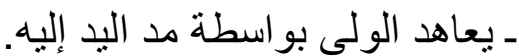

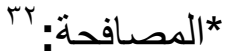
ـ الأخذ بالبد و التصافح منلها (السيدة).

ب - بعض الممارسات السارية ( Initiatiques) و وتثمثل في :

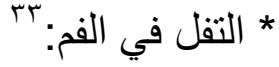

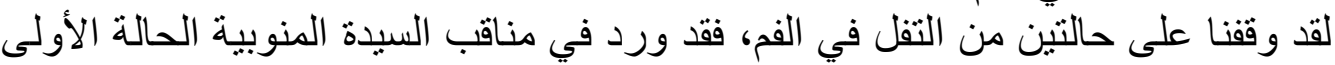

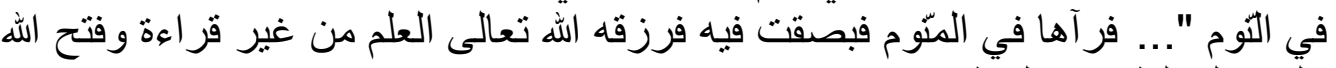

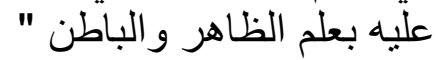

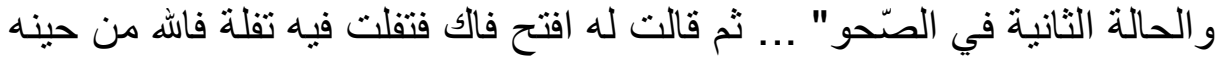

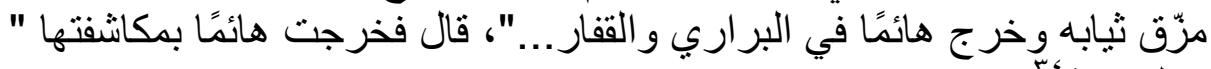

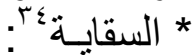

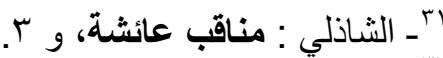
rr

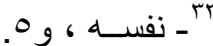

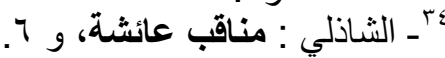




\section{لدراسات في آثار الوطن العربي 17}

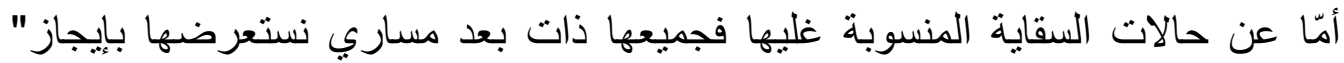

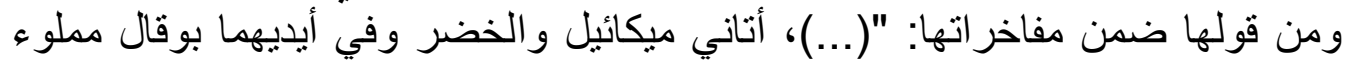

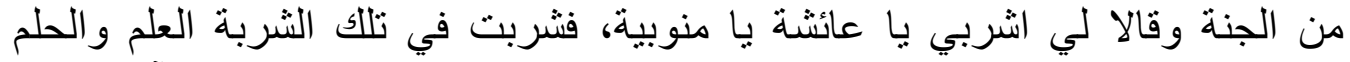

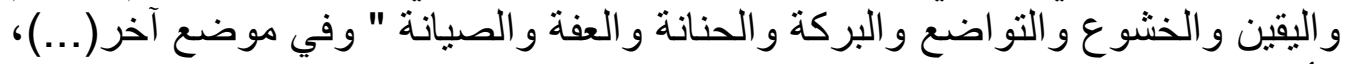

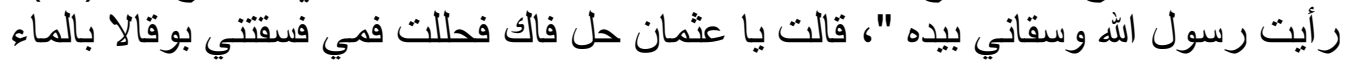

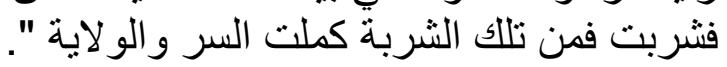

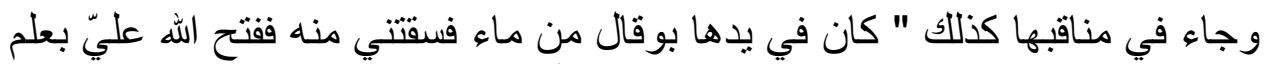

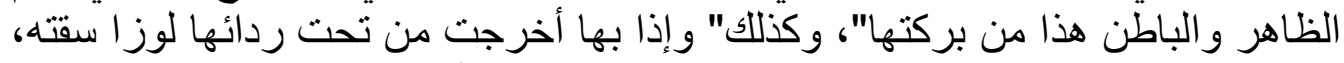

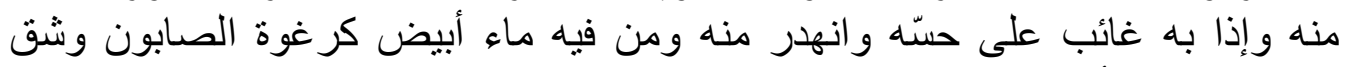

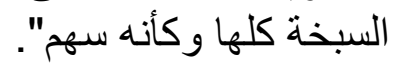
جـ - بعض الممارسات الثفائية ، منها:

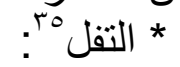

ينسب التفل إلى الرسول صلّى الله عليه وسلّم حيث أوصى أصحابه بالتفل

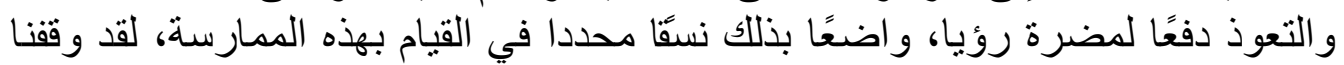

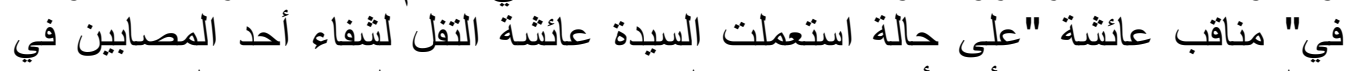

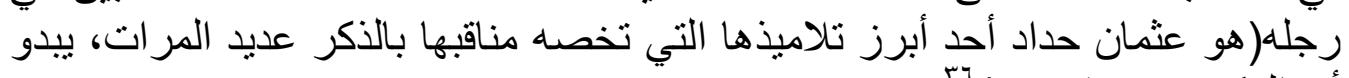

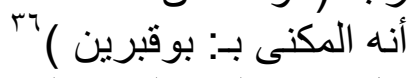

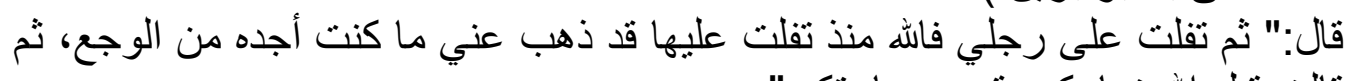
قالت قبل الله زياركم وقضى رجي حاجتكم ".

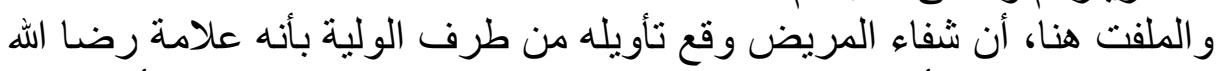

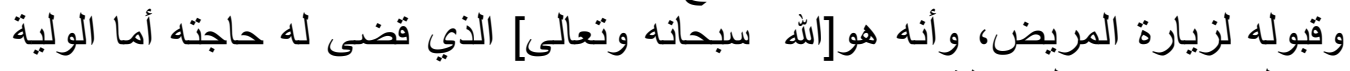

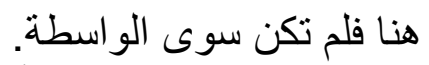
ولسنا ندري إلى أي ددى صحة البة هذه الطرق الثفائية، علما أن هذا النوع من التداوي لا زال مستمر ا إلى يومنا هذا.

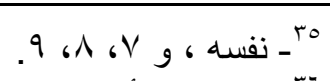

"جـ- نفسه ، لم أقف على تعريفه. 
داسات في آثار الوطن العربي 17

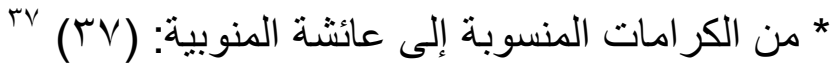
بالإمكان تبويب هذه الكرامات حسب التصنية التصنيف الذي اعتمدناه على النحو التالي

\begin{tabular}{|c|c|c|}
\hline المصــــــر & عددها & نـــــوع الكرامـــة \\
\hline مناقب عائشة: و 17 & 1 & إنز ال الغيث و إخصاب الزرع \\
\hline IV g & 1 & فلك الأســر. \\
\hline$r \varepsilon \sigma r \cdot g$ & r & إغـاثة المسـافرين \\
\hline$r \cdot ، \cdot \cdot 170$ g & $r$ & الإبـــــر اء \\
\hline IV، II & r & تأمين من لجأ إليها على حياته \\
\hline 9 & r & إعـادة الذاكرة \\
\hline & 11 & المجمـــــــوع \\
\hline
\end{tabular}

استخلصنا من هذه الإطلالة الخاطفة مجمو عة من الاستتناجات منها:

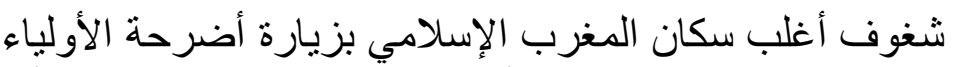

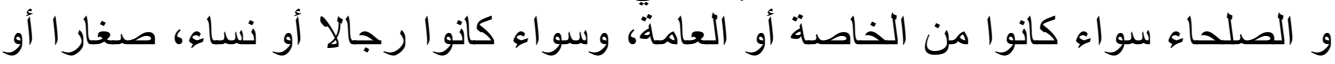

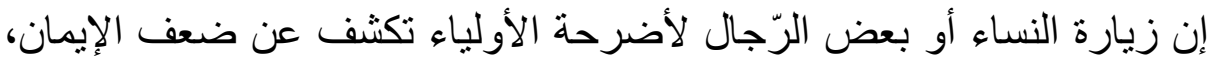

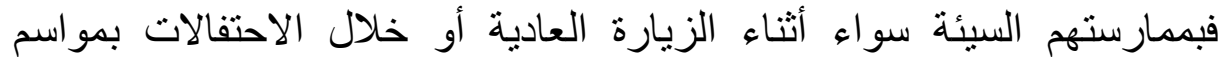

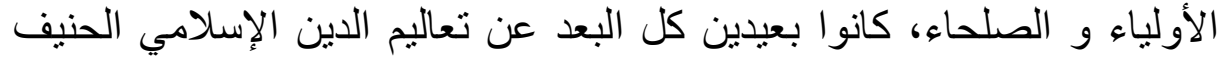

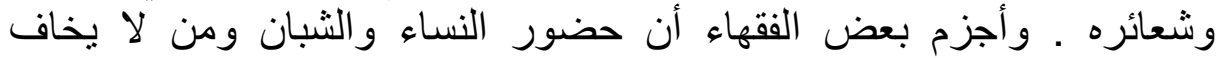
الباري تعالى كان يتسبب في عدد من المناكر و الأمور الثنيعة النياء.

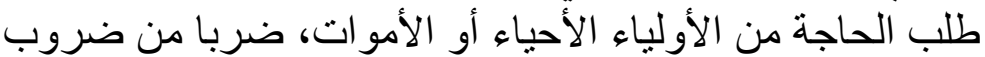

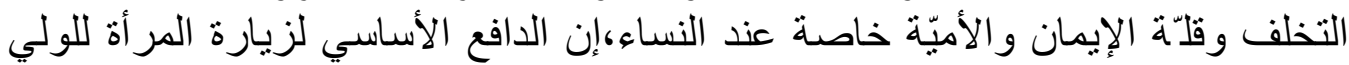

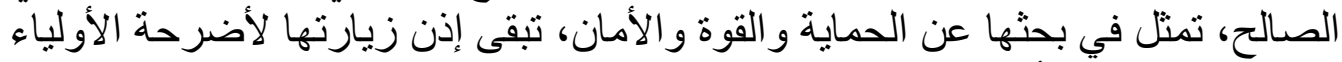

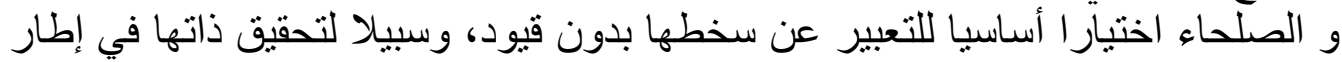
مقتصر على النساء ، و البحث عن الأمان و السعادة.

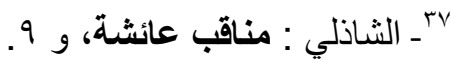


خلاصة القول نستنتج التقاط التنالية:

ا. الحفاظ على موروث المخطوطات، و و النتعور بقيمته لأثه أحد الوسائل التي تعرفنا

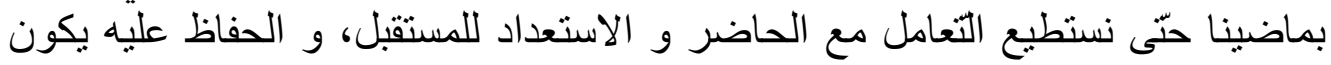

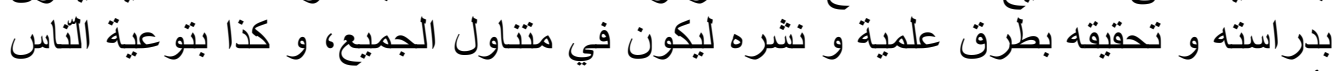
بأهيّته لكونه يمثل جذور الحضارة العريقة.

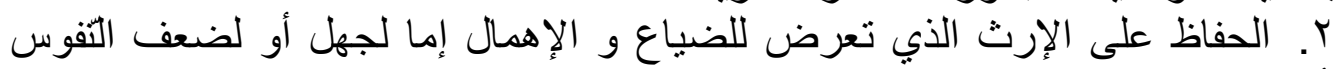

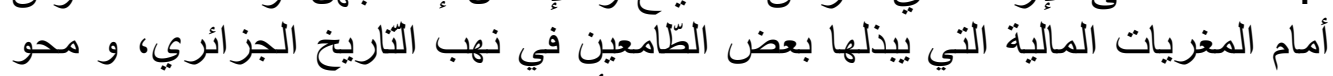

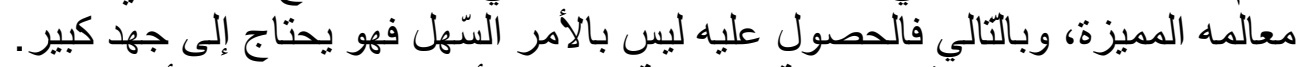

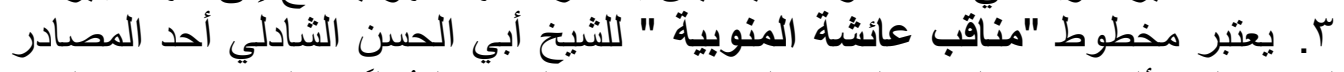

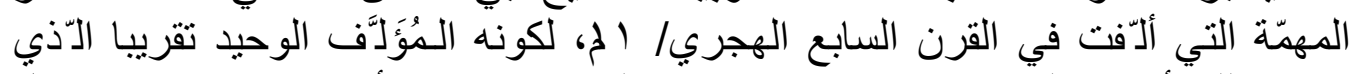

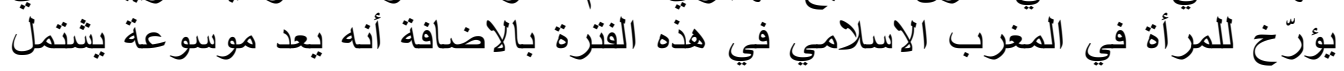

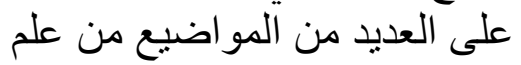

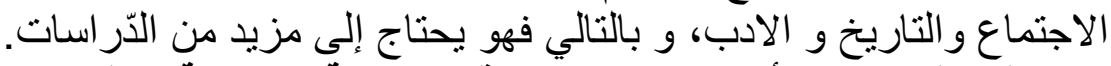

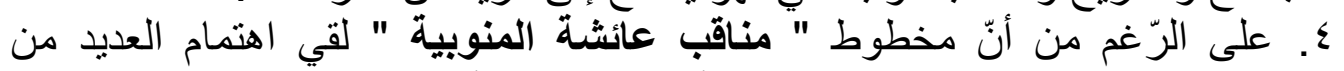

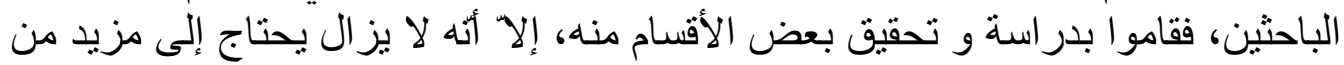

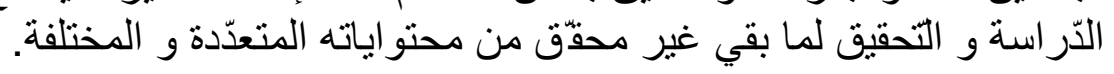


17

قائمة المصادر و المراجع: - مات

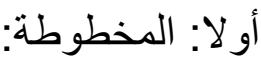

اــ الثاذلي،أبو الحسن: مناقب العيدة عائشة المنوبية ، مخطوط بدار الكتب الوطنية

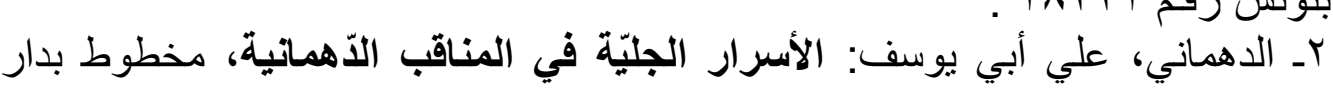

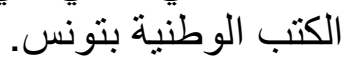

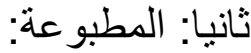
rــ الكتاني: سلوة الأنفاس ومحادثة الأكياس بمن أقبر من العلماء والصلحاء بفاس، ط

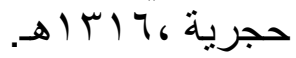

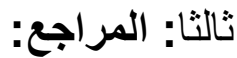

ع ـ التونجي محمّد: المنهاج في تأليف البحوث و تحقيق المخطوطات، عالم الكتب، حلب، هـ زيدان يوسف: تراثنا التّراث المجهول إطلالة على عالم المخطوطات، طب، دار

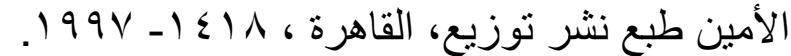

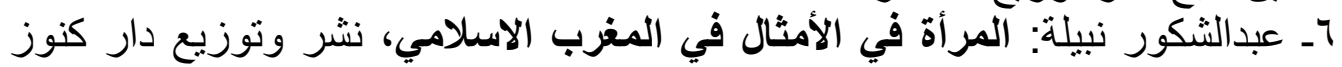

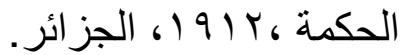
GHRAB (S) :IBN ARAFA et le Malikisme en Ifriqiya au 8h14,Tunis, 1992. 
17 دراسات في آثار الوطن العربي

\section{Résume :}

Le manuscrit intitulé «Biographie de Aicha El Manoubia» est considéré parmi les plus importantes sources conservées a la femme soufie au Maghreb islamique.

Ce manuscrit qui englobe 217 feuilles, et composé de 3 parties :

1- La première partie est consacrée aux recherches visant l'identification de la femme pieuse «AL WALIYA ASSALIHA $\gg$.

2- La deuxième partie correspond aux exemples relatifs aux qualités et dons qui distinguent cette femme pieuse « AICHA ».

3- La troisième partie est consacrée à la relation spirituelle de cette femme avec le prophète Mohammed (QSSL), ses compagnons et les gens du bien (AOULIAS ESSALIHINES). 


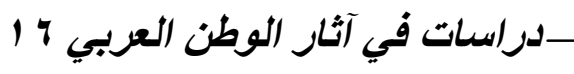

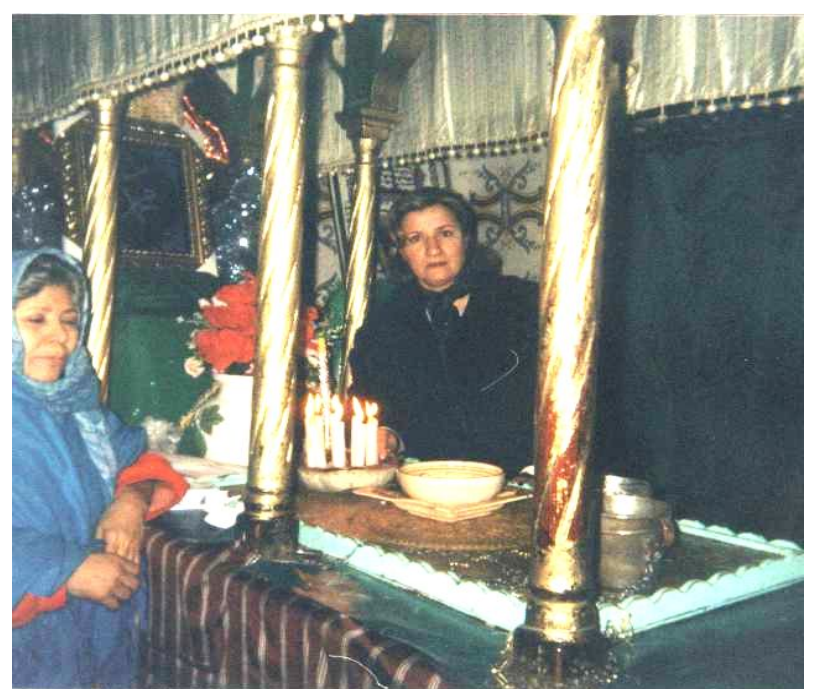

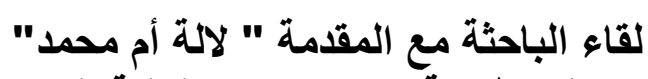
تشرح لها طريقة زيارة ضريح الولية المنوبية

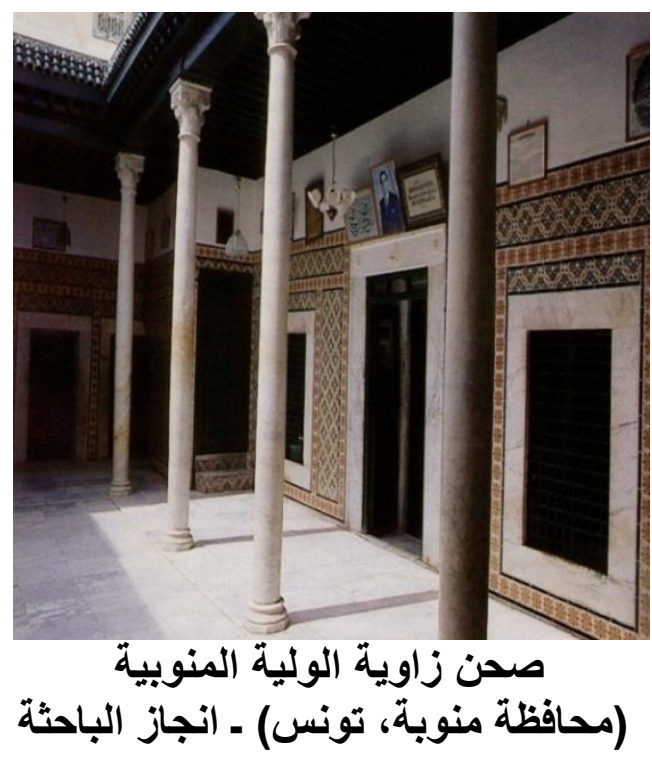

